\title{
Open Innovation And Risk Governence On Entrepreneurial Behaviors
}

Entrepreneurial Orientation merupakan sebuah penentu tindakan yang akan diambil oleh perusahaan dalam menemukan dan memanfaatkan peluang kewirausahaan (Wang, et al., 2020). Salah satu pendekatan yang fleksibel dengan menawarkan berbagai cara, dimana ide lebih mudah untuk dikembangkan adalah Open Innovation. Yang tidak hanya menitik beratkan sumber daya internal, tetapi juga inovasi teknologi yang digunakan perusahaan dalam proses meningkatkan open innovation. Inovasi ini berupa kerja sama, kolaborasi, aliran pengetahuan lancar sehingga dapat menciptakan output inovasi yang kompetitif (Mubarak \& Petraite, 2020). Risk Governance, merupakan sebuah pendekatan karakter ketidakpastian dalam suatu perusahaan. Pendekatan tersebut dapat diaplikasikan oleh masyarakat guna meminimalisir konsekuensi hal negatif dari risiko terkait melalui Risk Governance (Georlandt, 2020).

Dalam konsep open inovation, turut melibatkan variabel struktur jaringan, kepercayaan, pengembangan produk, dan kinerja perusahaan. Dimana memiliki keterkaitan antar variabel satu dengan lainnya. Perusahaan membutuhkan strukut jaringan dalam proses pengembangan produk, sedangkan kepercayaan memegang kendali dalam proses open innovation, yang melalui hubungan keterkaitan antara strukur jaringan dan pengembangan produk serta kinerja perusahaan (Pratono, 2018a). Pengukuran tingkat risk governance menggunakan metode pengukuran subjektif, yaitu Likert Scale. Dengan mengaplikasikan skala tolak ukur yang didalamnya terdapat pertanyaan meliputi kecenderungan yang besar dalam proyek untuk resiko tinggi, Tindakan yang tegas dan widening, membiayai bisnis baru, melakukan bisnis tanpa sumber daya yang cukup, pertumbuhan yang tinggi ditengah ketidakpastian dan cenderung cepat menghabiskan uang dalam sebuah solusi yang kuat (Pratono, 2018b)

\section{References}

Georlandt, F. (2020). Maritime Autonomous Surface Ships from a risk governance perspective : Interpretation and implications. Safety Science, 128 (2020), 3-5. 
Mubarak \& Petraite. (2020). Industry 4.0 technologies, digital trust and technological orientation: What matters in open innovation? Technological Forecasting \& Social Change, 161 (2020), 5-10.

Pratono, A. H. (2018a). Network structure and open innovation: the role of trust in product development. International Journal of Business Innovation and Research, 15(1), 53 54.

Pratono, A. H. (2018b). Does firm performance increase with risk-taking behavior under information technological turbulence?: Empirical evidence from Indonesian SMEs. The Journal of Risk Finance, 19(4), 361-378.

Wang, et al. (2020). Understanding firms' relative strategic emphases : An entrepreneurial orientation explanation. Industrial Marketing Management, 84 (2020), 151-164. 